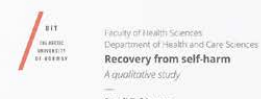

\title{
Ny avhandling om selvskading: Recovery from self-harm
}

\section{Førsteamanuensis Randi Tofthagen (PhD) ved Lovisenberg Diakonale høgskole disputerte 1. mai 2018 med avhandlingen: Recovery from self-harm.}

AVHANDLINGENS HOVEDHENSIKT var å øke forståelsen av recovery fra selvskade hos voksne mennesker giennom tre delstudier. I den første studien ble begrepet «selvskade» analysert innenfor konteksten av medisin og sykepleievitenskap. Den andre studien bygget på kvalitative interviu med spesialsykepleiere i forhold til deres erfaring med utøvelse av sykepleie til voksne pasienter med selvskade i en akuttfase. Den siste studien bygget på kvalitative interviu med personer som tidligere hadde selvskadet og siktet mot å forstå deres erfaringer med recovery.

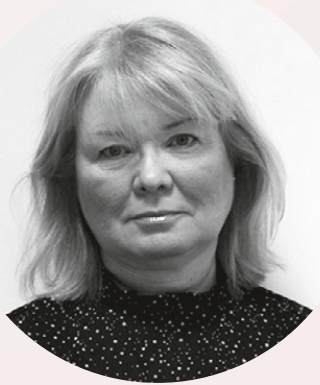

